\title{
COOPERATIVE TECHNIQUE
}

\author{
C. E. MCCLUNG
}

Zoological Laboratory, University of Pennsylvania, Philadelphia, Pa.

A realization of the very great influence that technique has upon the character of the results obtained in microscopical studies doubtless has come home to every one with extended experience in this kind of work. Time serves only to strengthen the conviction that good methods of preparation are absolutely essential to worthy results. It would be going too far to say that this conviction is universal, otherwise we should have been spared much worthless and troublesome publication, but it can safely be said that there is more general appreciation of the refinements of microscopical methods each year. Up to the present most of our processes are the heritage from the pioneers in this field who gained them through purely empirical means. Comparatively little has been added within recent years. The time would seem to have come to undertake a serious study of the problems in this field with the hope of attaining a fuller knowledge of the processes upon which we are so dependent for all progress in our investigations. It is a most hopeful sign that many biologists are devoting careful attention to this phase of their work and that more precise results are now obtainable than formerly was the case. While much of this advance has resulted from mitochondrial studies, the whole subject of microscopic anatomy has benefited from the greater precision here demonstrated.

But when the individual investigator, thus convinced of the need for advance, faces the prospect of such an extended investigation as would be necessary to developing general principles of operation, applicable to a variety of organisms and tissues, he hesitates to undertake a course which would divert so much of his limited time to methods of preparation. The usual result is that he seeks out the most satisfactory means for han- 
dling his own particular materials and contents himself with the best results obtained. Considering the welfare of the whole fraternity of microscopic anatomists this is a wasteful and time consuming method, because it requires, that, in large part, each investigator must work out his own technique and when he has done so his results to a considerable degree benefit only himself.

It would seem that there is a place here for the methods of combination and cooperation which have been so effective in business operations. That this thought is in the minds of not a few biologists is apparent from the inquiries that have come to me regarding the possibility of extending the investigations that are being carried on in the Zoology Department of the University of Pennsylvania to other objects than the ones serving there as objects of study. The increasing frequency of these has led me to consider the advisability of proposing a concerted series of studies upon technical processes, applicable to as wide a range of materials as our investigators have experience with, in the hope of developing more reasonable and more generally applicable preparation methods. In connection with such a series of studies there might be built up at some central place a collection of preparations, each the work of a specialist on some group, organ, tissue or cell, from which would be loaned for study and comparison, such slides as an investigator might need. In addition the results of these technical investigations might be published either separately or collected together and reduced to a more compact form. With the method and its results before him an investigator could determine whether he had attained success in his technique. It is probable that all microscopic anatomists are interested in this phase of their work and disposed to further it, but I do not know how many are convinced that advantage would accrue from a concerted series of studies or, if convinced, are disposed, or able, to cooperate. In the hope of determining whether it is possible to inaugurate correlated studies I am writing this note with the request that any who are interested send me their suggestions upon the subject. If the plan seems feasible I shall be glad to further it in any way possible. 